\title{
Bemutatkozik a Magyar Gyógyszerészi Kamara
}

\author{
On the Hungarian Chamber of Pharmacists
}

\author{
Szerzők: Hankó Zoltán $\square$ \\ Magyar Gyógyszerészeti Kamara
}

Beküldve: 2018. 03. 09.

doi: 10.24365/ef.v59i1.252

Kulcsszavak: gyógyszerészet, kamara

Keywords: pharmacists, chamber

\section{TÖRTÉNETE}

A Magyar Gyógyszerészi Kamara 1989 nyarán alakult a gyógyszerésztársadalom önkéntes elhatározásával. Az akkor hatályos egyesülési jogról szóló törvény alapján létrehozott szakmai érdekvédelmi szervezet a gyógyszerészet szakmai, erkölcsi és anyagi rehabilitációját túzte ki célul, amely közel ötezer fős önkéntes tagságával hamarosan a magyar gyógyszerészet legnagyobb taglétszámú szervezetévé vált. A kamara részt vett a gyógyszerészet rendszerváltó törvényeinek előkészítésében, szorgalmazta a gyógyszertárak privatizációját, és etikai normákat határozott meg a gyakorló gyógyszerészeknek.

A kamara köztestületként 1994 óta múködik, amikor az Országgyúlés törvényt alkotott a Magyar Gyógyszerész Kamaráról (1994. évi LI. törvény). A törvény rögzítette a kamara szervezetének és múködésének legfontosabb paramétereit, nevesítette szakmai érdekvédelmi jogköreit, elismerte a gyógyszerészek jogát a szakmai önkormányzat múködtetésére, felhatalmazta a kamarát a hivatásetikai szabályozás megalkotására és a szakmai/etikai normák betartatása érdekében valamennyi gyógyszerésznek előírta a kötelező kamarai tagságot. Ebben az időben - a nyugdíjasokkal együtt a szervezet létszáma elérte a 8200 főt.
A gyógyszerellátás liberalizálásával párhuzamosan az Országgyúlés 2006-ban - az orvosi kamaráról és egészségügyi szakdolgozói kamaráról szóló törvénnyel együtt - hatálytalanította a Magyar Gyógyszerész Kamaráról szóló 1994. évi LI. sz. törvényt és új jogszabályt alkotott az egészségügyben múködő szakmai kamarákról (2006. évi XCVII. tv). Ez a törvény együtt szabályozza az orvosi, a szakdolgozói és a gyógyszerészi kamara múködését. Az új szabályozás kiüresítette a kamara köztestületi jogköreit: megszüntette a kötelező kamarai tagságot, elvette a kamara hatósági jogköreit és visszavonta a kamara gyógyszertár-létesítésben és -múködtetésben, valamint személyi jog adományozásban korábban betöltött feladatkörét. A kötelező tagság megszüntetése, a kamara etikai szerepkörét is gátolta.

A kamara tudatos ellehetetlenítése és a gyógyszerpiaci liberalizáció között egyértelmű összefüggés volt, amely hatására néhány éven belül súlyos gazdasági, szakmai és morális válság alakult ki. Ezért a kamara teljes joggal, konkrét célként fogalmazta meg a patikaliberalizáció leállítását, a gyógyszertárak gazdasági múködőképességének biztositását, a gyógyszerészi kompetenciák helyreállítását és fejlesztését, valamint "köztestületiségének” visszaállítását. A kamarai jogkörök megvonása, a liberalizációval járó nehézségek és a gazdasági válság ellenére a kamara önkéntes tagjainak a száma 2010 elején is elérte a 4500 főt. 
A 2010-es kormányváltást követően az új kormányzat szakított elődje politikájával és a kamarával együttmúködve korrigálta a lakossági gyógyszerellátás szabályozását. Ennek eredményeként a gyógyszertárak létesítésének szabályozásában újra érvényesül a szükségleti elv, a gyógyszertárak működtetésében a személyes felelősség elve, 2017. január 1-től minden gyógyszertárat múködtető gazdasági társaságban többségi gyógyszerészi tulajdont kell biztosítani. Bár sok vitával járt a gyógyszerellátás strukturális alapjainak rendezése, egy kötelezettségszegési eljárás végén 2017-ben az Európai Unió bírósága is jóváhagyta a hazai szabályozás új elveit.

\section{A JELEN}

Az egészségügyben múködő szakmai kamarákról szóló 2006. évi XCVII. törvény átfogó módosításával sikerült helyreállítani a kamara köztestületiségét: az új szabályozás értelmében ismét kötelező a kamarai tagság az egészségügyi szolgáltatóknál működő gyógyszerészeknek. E mellett az érdekvédelmi testület megkapta a felhatalmazást egy egységes szakmai-etikai kódex létrehozására is. A kamarai törvény módosítása 2011. április 1-jétől hatályos. Miközben a jelenlegi szabályozás alapján a kötelező tagsági viszony kb. 5900 gyógyszerészt érint, jelenleg a létszám meghaladja a 8900 főt. Az önkéntes tagok nagy száma azt jelzi, a gyógyszerészek fontosnak tartják a kamarát.

A kamara, tagjaival az Országos Hivatal közremúködésével és megyei szervezetein keresztül aktív kapcsolatot tart. Konferenciákat és továbbképzéseket szervez, az aktuális szakmapolitikai problémák feltárására és megoldására miniszimpóziumokat tart. 1989-től megjelenő havi folyóirat, a Gyógyszerészi Hírlap mellett, 2009-től minden második héten elektronikus Hírlevélben kapnak tájékoztatást a tagok a gyógyszerészetet érintő aktuális hírekről és a tevékenységéről. A kamara honlapot is múködtet, melynek zárt része csak tagjai számára teszi elérhető. A gyógyszerészek és a betegek közötti kommunikációt segíti a kamara többségi tulajdonában működő Galenus kiadó által megjelentetett, patikai terjesztésủ ingyenes Patika Magazin.
A kamara a közpolitika kormányzati, hatósági és önkormányzati irányítóival kiegyensúlyozott munkakapcsolatot ápol. Politikai pártoktól független, de valamennyi politikai erővel együttmúködésre kész az egészségügy és a gyógyszerellátás zavartalan múködési feltételeinek biztosításáért.

A kamara szorosan összedolgozik az egészségügyben múködő más szakmai kamarákkal, együttmúködésre törekszik valamennyi gyógyszerészi szakmaitudományos és érdekvédelmi szervezettel és élő kapcsolatot tart fenn a gyógyszerészképző egyetemekkel. A kamara alapító tagja a Magyar Szakmai Kamarák Szövetségének, tagot delegál a NEAK (Nemzeti Egészségbiztosítási Alapkezelő) gyógyszerbefogadásokat elbíráló bizottságába. Egyik alapítója a Gyógyszerészi Gondozás Szakmai Bizottságnak. A kamara széleskörú kapcsolatokat ápol nemzetközi gyógyszerészeti szervezetekkel (pl. Pharmaceutical Group of the European Union) és a környező országok gyógyszerészkamaráival.

A kamara a jogszabályokat, szakmai előírásokat és etikai normákat múködése során betartja és ezt a tagjaitól is elvárja. Elkötelezett a biztonságos, minőségi és költséghatékony gyógyszerellátás mellett, fontosnak tartja a betegek érdekeinek érvényesülését. Fontos, hogy az Európai Közösség Bíróságának gyógyszerészettel kapcsolatos 2009. május 19-i határozataiban és a 2011. január 1-én életbe lépett hazai szabályozásban megfogalmazott elvek a gyógyszerellátásban minél teljesebb körűen valósuljanak meg. A kamara alapvető célkitǔzéseit a kamara alapszabályának Célok és feladatok c. fejezete foglalja össze (http://mgyk.hu/admin/data/file/4999 20160402-alapszabaly ell.pdf).

A fentebb említett strukturális rendszerváltás lezárását követően a kamara feladatai közé tartozik, a lakossági gyógyszerellátásban a szakmai rendszerváltás végig vitele. Álláspontunk szerint a gyógyszerellátás biztonságának, minőségének és hatékonyságának legfőbb garanciája a jól felkészült és a hivatásetikai szabályokat a munkájában érvényesítő, szakmailag és egzisztenciálisan független gyógyszerész. Ezért is fontos a gyógyszerészekkel szemben támasztott társadalmi elvárások érvénye- 
sítéséhez szükséges feltételek megteremtése és a jogos elvárásokhoz szükséges gyógyszerészi kompetenciák biztosítása. Úgyszintén fontos célkitűzés a fekvőbeteg-ellátásban a gyógyszerészi szolgáltatások megújítása, továbbá a gyógyszeriparban a gyógyszerészek speciális felkészültségének megfelelő foglalkoztatási körülmények kialakítása. A kamara törekvése, hogy köztestületi jogosítványait visszakapva a gyógyszerészek önkormányzataként működhessen, szakmai érdekképviseleti munkáját a betegérdekek figyelembe vételével végezze és a gyógyszerészi tevékenység etikai őre legyen.

\section{A KAMARA EDDIGI ELNÖKEI}

1989-1990: Prof. dr. Vincze Zoltán

1990-1998: Dr. Szabó Sándor

1998-2006: Hávelné dr. Szatmári Katalin

2006-2011: Dr. Horváth Tamás

2011- : Dr. Hankó Zoltán

További részletek a Kamara honlapján: http://mgyk.hu/ 